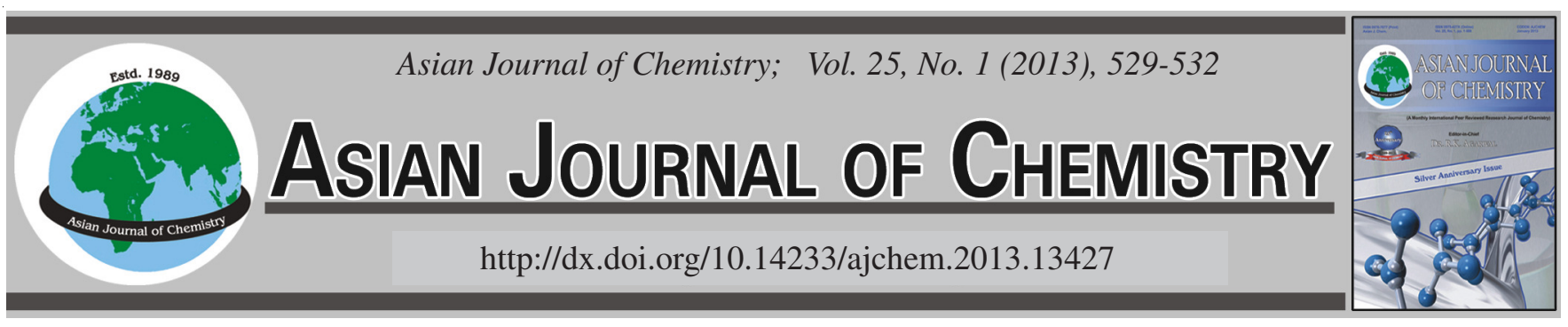

\title{
Determination of Human Serum Albumin with Tetra-amino Copper Phthalocyanine by Resonance Light Scattering Technique
}

\author{
Zhongun Xue ${ }^{1}$, Xuejun Zhang ${ }^{2, *}$, GaO WAng $^{3}$, Dan Zhang ${ }^{2}$ and Hanchang Zhou ${ }^{1}$
}

${ }^{1}$ Key Laboratory of Instrumentation Science and Dynamic, Measurement of Ministry of Education, North University of China, Taiyuan 030051, Shanxi Province, P.R. China

${ }^{2}$ Department of Chemistry, College of Science, North University of China, Taiyuan 030051, Shanxi Province, P.R. China

${ }^{3}$ National Key Laboratory of Science and Technology on Electronic Test and Measurement, North University of China, Taiyuan 030051, Shanxi Province, P.R. China

*Corresponding author: Fax: +86 351 3922152; Tel: +86 351 3922152; E-mail: 1zhx@ nuc.edu.cn

(Received: 11 January 2012;

Accepted: 4 August 2012)

AJC-11918

\begin{abstract}
Resonance light scattering has been extensively used in the detection of concentrations of biological macromolecules. For the development of resonance light scattering based protein detection sensor at the point-of-care, it is necessary to make the enhanced resonance light scattering wavelength move to long wave direction to improve the detection sensitivity. A method for determination of protein was developed in presence of tetra-amino copper phthalocyanine (TACuPc) by resonance light scattering technique. In acidic solution, the interaction between TACuPc and human serum albumin yielded strongly enhanced resonance light scattering signals at wavelength 454 $\mathrm{nm}$ and the enhanced intensity of resonance light scattering was proportional to the concentration of proteins. The effects of $\mathrm{pH}$ and interfering species on the determination of protein were examined. Under optimal conditions, the linear range of human serum albumin is $0-2 \mu \mathrm{g} \mathrm{mL} \mathrm{m}^{-1}$ and the detection limit is $19.37 \mathrm{ng} \mathrm{mL}^{-1}$.
\end{abstract}

Key Words: Protein, Human serum albumin, Resonance light scattering, Tetra-amino copper phthalocyanine.

ᄂ _ _ - - - - - _ - - - - - - - - - - - - - - - - - - -

\section{INTRODUCTION}

The quantitative analysis of protein is of great importance in biochemistry and clinical application because it can provide information for diagnosis of diseases and measure of other components. The traditional methods for the quantitative determination of protein are the Lowry ${ }^{1}$, Bradford ${ }^{2,3}$, bromophenol blue ${ }^{4,5}$ and bromocresol green ${ }^{6}$. Some new methods were also developed, such as spectrophotometric ${ }^{7}$, fluorimetric ${ }^{8,9}$ and chemiluminescent ${ }^{10}$ methods. However, most of these methods suffer from the disadvantage of low sensitivity, strong sorption, poor selectivity, the toxicity and high costs of the fluorescence reagents, relatively long analytical time.

Resonance light scattering is a special elastic scattering produced when the wavelength of Rayleigh scattering is located at or close to its molecular absorption. Pasternack et al. ${ }^{11}$ firstly established a sensitive and simple resonance light scattering technique to study the biological macromolecules with a common fluorescence spectrometer. Huang et al. ${ }^{12}$ employed resonance light scattering technique to establish a high sensitive method for DNA determination. Hence, resonance light scattering technique has become a new interesting method for the determination of biological molecules, such as nucleic acids ${ }^{13,14}$, proteins ${ }^{15}$, aggregated porphyrin ${ }^{16}$ and sugar ${ }^{17}$. Commonly, the peak spectral sensitivity of silicon photodetector is located at near infrared. If the protein can enhance the resonance light scattering signal and shift to near infrared, it will create condition for determination of protein with detection sensors at the point-of-care. Phthalocyanines have strong absorption of visible radiation between 600 and $850 \mathrm{~nm}$. In this study, it was found that the tetra-amino copper phthalocyanine (TACuPc) and human serum albumin (HSA) yielded strongly enhanced resonance light scattering signals in an acidic solution. The enhanced intensity of resonance light scattering was proportional to the concentration of human serum albumin. The method has been applied to the determination of total proteins in human serum albumin samples with satisfactory results.

\section{EXPERIMENTAL}

Intensity and spectra of resonance light scattering were obtained with an F-2500 spectrofluorimeter (Hitachi Ltd., Tokyo Japan). A quartz cuvette $(1 \times 1 \mathrm{~cm}$ cross-section) was used. The absorption spectra were made on a UV-2300 spectrophoto- 
meter (Tianmei, Shanghai, China). All the $\mathrm{pH}$ measurements were made with a model pHs-301 pH meter (Xiamen, China).

Tetra-amino copper phthalocyanine was synthesized and purified as described ${ }^{18}$. The product was identified by polyamide thin layer chromatography, UV-VIS absorption spectrum, fluorescence spectra and infrared spectrum. A stock solution of 1.0 $\times 10^{-4} \mathrm{~mol} \mathrm{~L}^{-1}$ was prepared in dimethyl sulfoxide.

The standard solutions of human serum albumin (Hua-Mei Biochemical Reagent, China) was directly dissolved in water to prepare stock solutions and stored at $0-4{ }^{\circ} \mathrm{C}$.

Five kinds of buffers, citric acid-sodium citrate, $\mathrm{KCl}-\mathrm{HCl}$, $\mathrm{Na}_{2} \mathrm{HPO}_{4}$-citric acid, potassium biphthalate- $\mathrm{HCl}$ and BrittonRobinson $\left[\left(\mathrm{H}_{3} \mathrm{PO}_{4}, \mathrm{HOAc}, \mathrm{H}_{3} \mathrm{BO}_{3}\right)-\mathrm{NaOH}\right]$ were used.

All chemical used were of analytical grade and redistilled deionized water was used throughout.

To a $10 \mathrm{~mL}$ calibrated tube was added $1 \mathrm{~mL}$ of BrittonRobinson buffer solution and an appropriate volume of TACuPc and amount of human serum albumin or sample solution successively, then diluted with water to the mark and mixed thoroughly. The resonance light scattering spectrum was recorded by scanning simultaneously the excitation and emission monochromators $(\Delta \lambda=0 \mathrm{~nm})$ of the F-2500 fluorescence spectrophotometer (with $5 \mathrm{~nm}$ slit width) from 300 to $700 \mathrm{~nm}$. The resonance light scattering intensity I for the reaction product and $\mathrm{I}_{0}$ for the reagent blank were measured at the maximum scattered wavelength, $\Delta \mathrm{I}=\mathrm{I}-\mathrm{I}_{0}$.

\section{RESULTS AND DISCUSSION}

Molecular structure of TACuPc: Fig. 1 is the molecular structure of TACuPc. The structure of its bulk moiety is similar to that of porphyrin, with four benzene rings substituted by a strongly polar amino group, respectively, in the periphery of the bulk moiety. Because of the introduction of four strongly polar amino groups, the solubility of phthalocyanine in water was greatly enhanced.

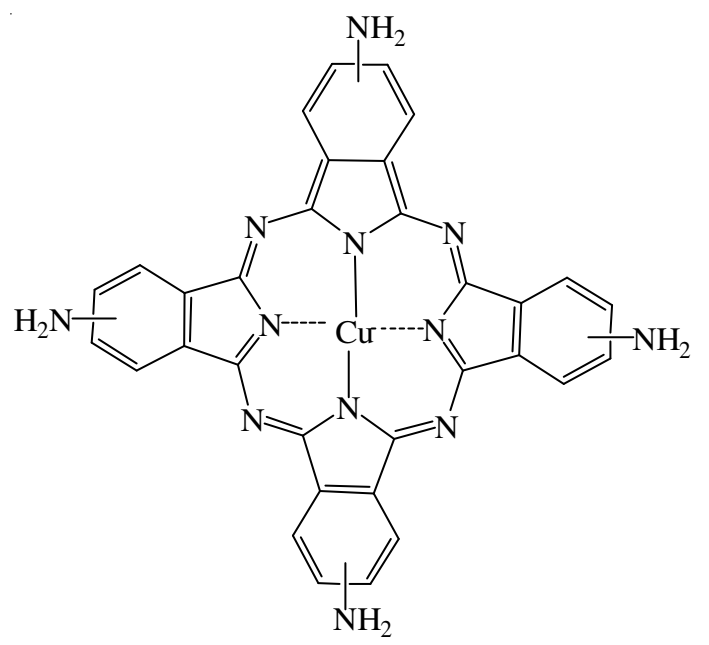

Fig. 1. Molecular structure of TACuPc

Spectral characteristics: The resonance light scattering spectra of TACuPc, human serum albumin and the mixture of $\mathrm{TACuPc}$ with human serum albumin are show in Fig. 2. It can be seen that the resonance light scattering intensities of TACuPc and human serum albumin are quite weak, respectively.
However, when adding human serum albumin to TACuPc or vice versa, a strong resonance light scattering signal can be observed at $454 \mathrm{~nm}$, which indicates that TACuPc and human serum albumin interact with each other. Moreover, the enhanced resonance light scattering intensity increases with the increasing HAS concentration. Therefore, $454 \mathrm{~nm}$ was selected as the analytical wavelength.

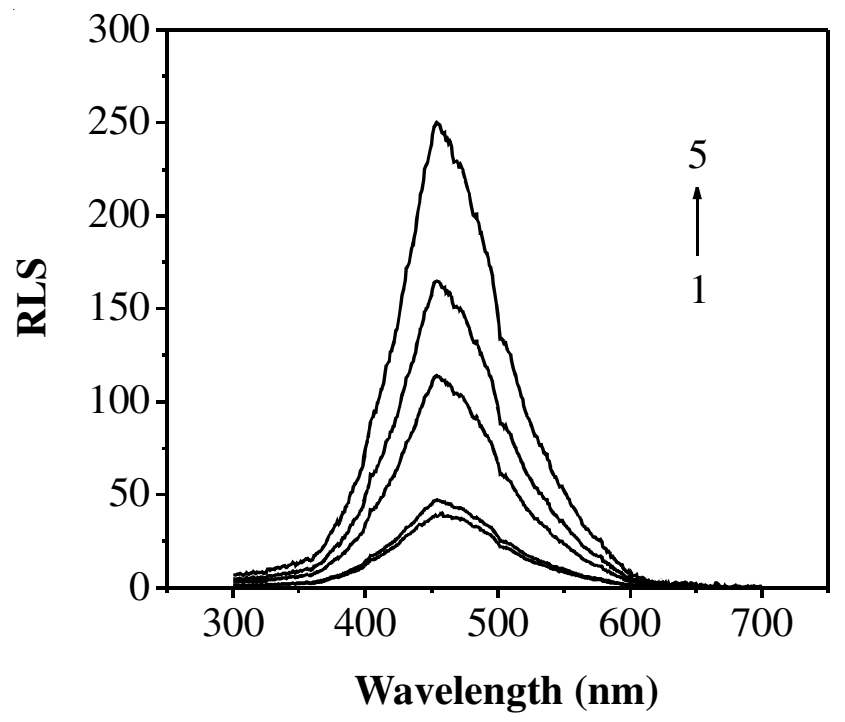

Fig. 2. Resonance light scattering (RLS) of human serum albumin (1); the effect of concentration of human serum albumin on the RLS spectra (2-5). TACuPc: $5.0 \times 10^{-5} \mathrm{~mol} \mathrm{~L}^{-1}$, human serum albumin $\left(\mu \mathrm{g} \mathrm{mL}^{-1}\right)$ : $1,1.0 ; 2,0.0 ; 3,0.25 ; 4,0.5 ; 5,1.0 . \mathrm{pH} 4.0$

Fig. 3 is the absorption spectra of TACuPc in the presence of human serum albumin. It is obvious that TACuPc has two absorption bands, a soret band and a $\mathrm{Q}$ band. As different concentrations of human serum albumin were mixed with TACuPc, no significant wavelength shift occurred for the peaks, however, the absorption peak at $720 \mathrm{~nm}$ obviously decreased with increasing amounts of human serum albumin. This further confirmed the strong interaction between TACuPc and human serum albumin.

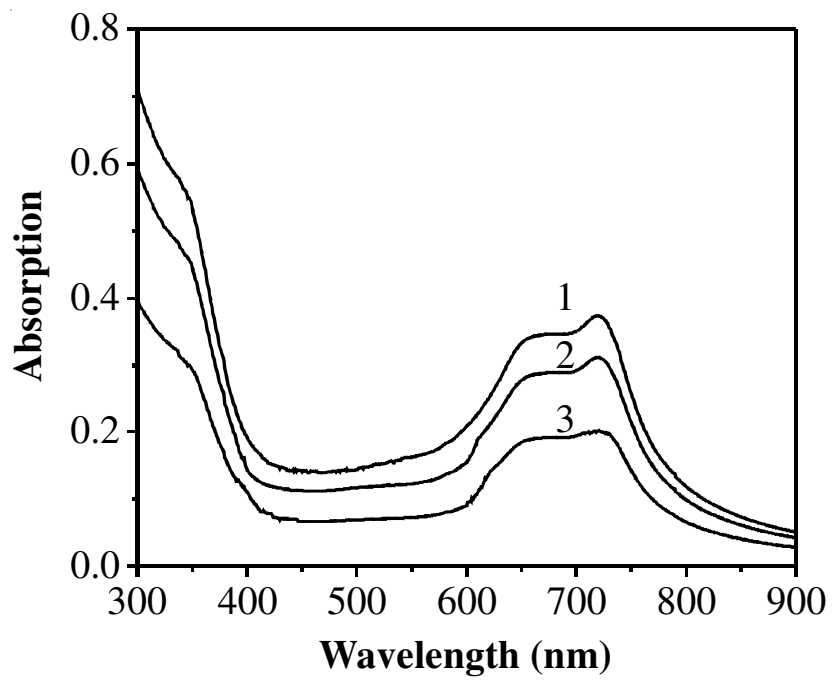

Fig. 3. Absorption spectra of TACuPc in the presence of human serum albumin. TACuPc, $1.0 \times 10^{-5} \mathrm{~mol} \mathrm{~L}^{-1}$; human serum albumin $(\mu \mathrm{g}$ $\left.\mathrm{mL}^{-1}\right), 1,0 ; 2,1.0 ; 3,2.0$ 
Stability: At room temperature, the intensity of resonance light scattering reaches quickly a maximum when all reagents are mixed together and the scattering intensity is stable for at least $3.0 \mathrm{~h}$. Therefore, $5 \mathrm{~min}$ of incubation time was recommended.

Effect of adding sequence of the reagents: The effect of the following adding sequence of the reagents on the sensitivity of this method was studied: buffer + human serum albumin + TACuPc, buffer + TACuPc + human serum albumin and TACuPc + human serum albumin + buffer. The results show the sequence of buffer + human serum albumin + TACuPc gives the best stabilities and intensities of resonance light scattering signals. Mixing the buffer and protein first provides positively charged protein for this combination and improves determination sensitivity. It is easy for negative charged TACuPc in weakly acidic solution $(\mathrm{pH} 4)$ to bind positively charged human serum albumin $(\mathrm{pH} \mathrm{4.7)}$. Under the neutral condition, if TACuPc is first mixed with human serum albumin then it is difficult for the negatively charged dye to bind the negatively charged human serum albumin.

Effect of $\mathbf{p H}$ and buffer: The influence of $\mathrm{pH}$ on resonance light scattering intensity was examined in the $\mathrm{pH}$ range 1.06.5 (Fig. 4). It can be seen that the optimum range of 2-4, an increase in $\mathrm{pH}$ leads to a reduction of the resonance light scattering signal. This is possibly related to the isoelectric point of the protein (human serum albumin, $\mathrm{pH} 4.7$ ). Before the

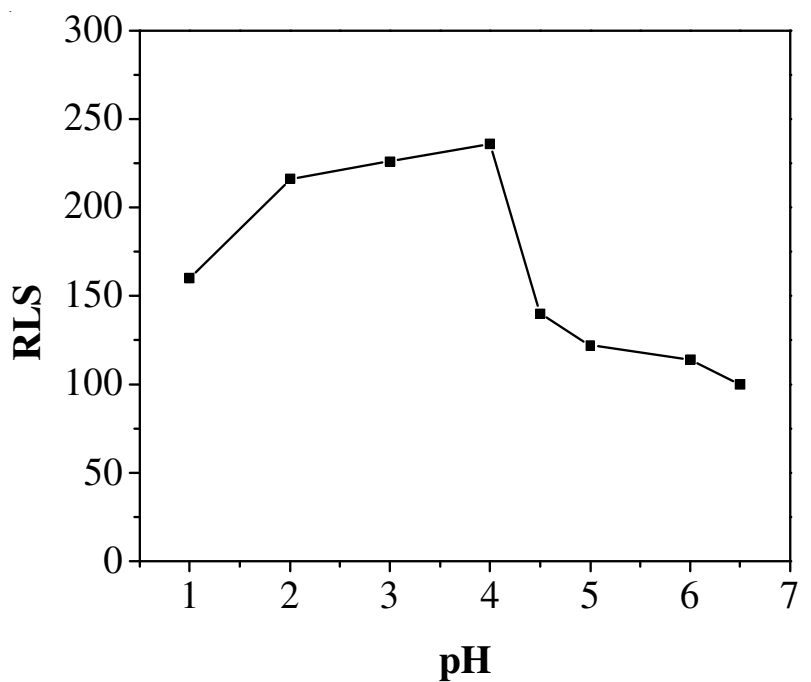

Fig. 4. Effect of $\mathrm{pH}$ on resonance light scattering (RLS) intensity. TACuPc, $5.0 \times 10^{-5} \mathrm{~mol} \mathrm{~L}^{-1}$; human serum albumin, $1.0 \mu \mathrm{g} \mathrm{mL}^{-1}$ isoelectric points, protein molecules are in positive charges and react with TACuPc anions by electrostatic interaction. As the $\mathrm{pH}$ approaches or exceeds the isoelectric point, protein molecules are neutral or in negative charge, thus the capability to reach with TACuPc is greatly weakened. Therefore, $\mathrm{pH} 4$ was chosen to run the assay.

Experimental results demonstrate that different kinds of buffers, citric acid-sodium citrate, $\mathrm{KCl}-\mathrm{HCl}, \mathrm{Na}_{2} \mathrm{HPO}_{4}$-citric acid, potassium biphthalate- $\mathrm{HCl}$ and Britton-Robinson, were tested and the results showed a similar changing trend with slightly different effect on the resonance light scattering signal. Britton-Robinson buffer was finally chosen.

Optimum amounts of TACuPc: The effect of TACuPc concentration on scattering intensity was examined. The results are shown in Fig. 5. It can be seen that more sensitivity and the widest linear range are reached at a TACuPc concentration of $5.0 \times 10^{-5} \mathrm{~mol} \mathrm{~L}^{-1}$. The concentration of $5.0 \times 10^{-5} \mathrm{~mol} \mathrm{~L}^{-1}$ was recommended.

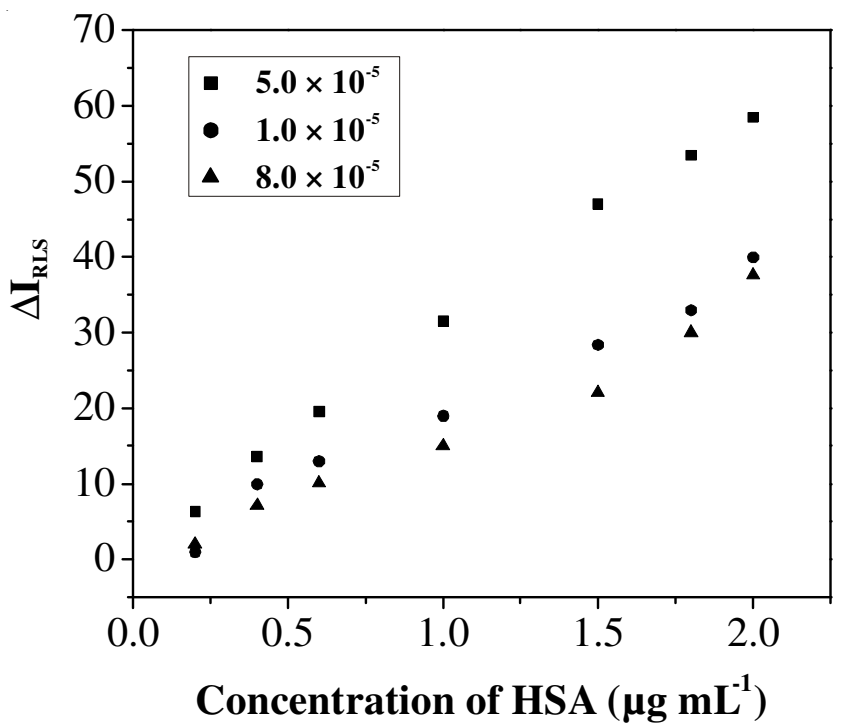

Fig. 5. Effect of TACuPc concentration on the intensity of resonance light scattering (RLS) at $\mathrm{pH} 4.0, \mathrm{TACuPc}\left(\times 10^{-5} \mathrm{~mol} \mathrm{~L}^{-1}\right)$

Interference: The influence of coexisting substance, such as metal ions and amino acids, was tested at $1.0 \mu \mathrm{g} \mathrm{mL}^{-1}$ human serum albumin. The experimental results are listed in Table-1. It can be seen that amino acids and ions hardly interfere with the determination.

TABLE-1

RATE CONSTANT (k) FOR 2HI $(\mathrm{g}) \rightarrow \mathrm{H}_{2}(\mathrm{~g})+\mathrm{I}_{2}(\mathrm{~g})$ AT ABSOLUTE TEMPERATURE $(\mathrm{T})^{\text {a }}$

\begin{tabular}{|c|c|c|c|c|c|}
\hline $\begin{array}{c}\text { Foreign } \\
\text { substance }\end{array}$ & $\begin{array}{c}\text { Maximum concentration } \\
\left(\mu \mathrm{g} \mathrm{mL}^{-1}\right)\end{array}$ & $\begin{array}{l}\text { Relative error } \\
\text { caused }(\%)\end{array}$ & $\begin{array}{l}\text { Foreign } \\
\text { substance }\end{array}$ & $\begin{array}{l}\text { Maximum concentration } \\
\left(\mu \mathrm{g} \mathrm{mL}^{-1}\right)\end{array}$ & $\begin{array}{l}\text { Relative error } \\
\text { caused }(\%)\end{array}$ \\
\hline $\mathrm{Ca}^{2+}$ (chloride) & 20 & 2.6 & Urea & 100 & -1.6 \\
\hline $\mathrm{K}^{+}$(chloride) & 25 & -2.1 & EDTA & 20 & 4.2 \\
\hline $\mathrm{Co}^{2+}$ (chloride) & 20 & 3.9 & Glucose & 50 & -4.7 \\
\hline $\mathrm{Fe}^{3+}$ (chloride) & 0.2 & 4.7 & L-Tryptophan & 4 & 3.7 \\
\hline $\mathrm{Cd}^{2+}$ (chloride) & 10 & 1.3 & Glycine & 10 & -2.9 \\
\hline $\mathrm{Mg}^{2+}$ (chloride) & 15 & 2.6 & L-Lyrosine & 75 & 4.8 \\
\hline $\mathrm{Mn}^{2+}$ (chloride) & 20 & 1.2 & D-Phenylalanine & 100 & 1.5 \\
\hline $\mathrm{Al}^{3+}$ (chloride) & 5 & 1.8 & $\mathrm{~Pb}^{2+}$ (Nitrate) & 5 & 2.5 \\
\hline $\mathrm{Zn}^{2+}$ (chloride) & 1 & 2.2 & L-Arginine & 100 & 4.1 \\
\hline $\mathrm{Na}^{+}$(chloride) & 20 & 2.4 & - & - & - \\
\hline
\end{tabular}


Effect of ionic strength: In a general system, the enhancement of the resonance light scattering signal strongly depends on the ionic strength solution. The interaction between human serum albumin and TACuPc is mainly a result of electrostatic forces, so the ionic strength should have some effect on this reaction. It was found that the resonance light scattering intensities are stable when the ionic strength is less than 0.1 mol $\mathrm{L}^{-1} \mathrm{NaCl}$ but decrease when the ionic strength is more than $0.1 \mathrm{~mol} \mathrm{~L}^{-1}$. This phenomenon is possibly due to the decrease of the electrostatic forces between TACuPc and human serum albumin, because the shielding effect of the charges on proteins increases with increasing ionic strength, which unprofitable for the formation of the complex.

Calibration graphs: Calibration graphs for the determination of proteins were constructed. Under the above optimal conditions, the difference of the light scattering intensity in the absence and presence of human serum albumin $(\Delta l)$ was proportional to the concentration of proteins with a good linear relationship. The linear regression equation is:

$$
\Delta l=1.639+29.91 \mathrm{C}, \mathrm{r}=0.9994
$$

A linear range is $0-2.0 \mu \mathrm{g} \mathrm{mL} \mathrm{L}^{-1}$, the detection limit is 19.37 ng $\mathrm{mL}^{-1}$

The limit of detection (LOD) was given by the equation $\mathrm{LOD}=\mathrm{KS}_{0} / \mathrm{S}$, where $\mathrm{K}$ is a numerical factor chosen according to the confidence level desired, $S_{0}$ is the standard deviation of the blank measurements ( $\mathrm{n}=9, \mathrm{~K}=3$ ) and $\mathrm{S}$ is the slope of the calibration curve. The relative standard deviations (RSD)

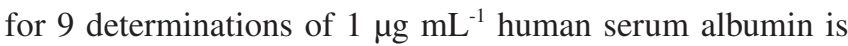
$2.1 \%$.

Determinations of total protein in human serum samples: Under the experimental conditions, the present method was used to determine total proteins in human serum samples obtained from the North University of China Hospital, stored at $0-4{ }^{\circ} \mathrm{C}$ and diluted 1000 -fold with deionized water for analysis. The results for the human serum samples are shown in Table-2. It can be seen that the results obtained by clinical physicians, which indicates this method has the potential in clinical assay.

TABLE-2

DETERMINATION OF PROTEIN IN HUMAN SERUM ${ }^{\mathrm{a}}$

\begin{tabular}{cccc}
\hline Sample & $\begin{array}{c}\text { Present method } \\
\left(\mathrm{mg} \mathrm{mL}^{-1}\right)\end{array}$ & RSD & $\begin{array}{c}\text { Clinical data } \\
\left(\mathrm{mg} \mathrm{mL}^{-1}\right)\end{array}$ \\
\hline 1 & 81.3 & 2.1 & 81.6 \\
2 & 76.8 & 2.3 & 76.9 \\
3 & 88.1 & 3.4 & 87.7 \\
4 & 82.4 & 3.9 & 83.1 \\
\hline a Each result was the average of five measurement
\end{tabular}

\section{Conclusion}

In the acidic environment, human serum albumin and negatively organic dye can produce electrostatic forces and form organic dye-protein complexes. At $\mathrm{pH} 4.0$, the interaction between human serum albumin and TACuPc yields strongly enhanced resonance light scattering signals. This new method using an ordinary spectrofluorimeter is sensitive and simple. It is shown that this method has great potential, high sensitivity, good stability, increased simplicity and lower detection limits for the determination of protein. And the method will create conditions for detection sensors at the point-of-care with silicon photodetectors.

\section{ACKNOWLEDGEMENTS}

The authors acknowledged the financial support from the National Nature Science Foundation of China (Grant No.: 20871108) and the Natural Science Foundation of Shanxi Province, China (Grant No.: 2011011022-4).

\section{REFERENCES}

1. O.H. Lowry, N.J. Rosebrough and R.J. Randall, J. Biol. Chem., 193, 265 (1951)

2. M.M. Bradford, Anal. Biochem., 72, 248 (1976).

3. T. Zor and Z. Selinger, Anal. Biochem., 236, 302 (1996).

4. R. Flores, Anal. Biochem., 88, 605 (1978).

5. S. Tayyab and M.A. Qasim, J. Biol. Macromol., 12, 55 (1990).

6. R.L. Rodkly, Arch. Biochem. Biophys., 108, 510 (1964).

7. I. Mori, K. Taguch, Y. Fujita and T. Matsuo, Anal. Lett., 28, 225 (1995).

8. C.Q. Ma, K.A. Li and S.Y. Tong, Anal. Chem. Acta, 333, 83 (1996).

9. N. Li, K.A. Li and S.Y. Tong, Anal. Biochem., 233, 151 (1996).

10. Z.P. Li, K.A. Li and S.Y. Tong, Anal. Lett., 32, 901 (1999).

11. R.F. Pasternack, C. Bustamante, P.J. Collings, A. Giannetto and E.J. Gibbs, J. Am. Chem. Soc., 115, 5393 (1993).

12. C.Z. Huang, K.A. Li and S.Y. Tong, Anal. Chem., 68, 2259 (1996).

13. Z.P. Li, K.A. Li and S.Y. Tong, Talanta, 55, 669 (2001).

14. P. Bao, A.G. Frotos, C. Greef, J. Lahiri, U. Muller, T.C. Peterson, L. Warden and X.Y. Xie, Anal. Chem., 74, 1792 (2002).

15. Y.J. Chen, J.H. Yang, X.Wu, T. Wu and Y.X. Luan, Talanta, 58, 869 (2002).

16. M.Y. Choi, J.A. Pollard, M.A. Webb and J.L. McHale, J. Am. Chem. Soc., 125, 810 (2003).

17. S.P. Liu, H.Q. Luo and N.B. Li, Anal. Chem., 73, 3907 (2001).

18. B.N. Achar and K.S. Lokesh, J. Org. Chem., 689, 3357 (2004) 